determination. Simple comparison of the solubilities of dusts using fixed conditions may give misleading results, and the correlation of solubility with pathological action by in vitro means will require a much more exhaustive study than has so far been attempted. In experiments designed to show the dissolution of dusts in the body, which will be reported elsewhere, cement has shown a relatively high solubility as compared with flint, sand (harmful dusts) and carborundum (harmless).

${ }^{1}$ Lenher, V., and Merrill, H. B., J. Amer. Chem. Soc., 39, 2630 (1917). ${ }^{2}$ Titus, A. C., J. Indust. Hyg. Toxic., 19, 138 (1937).

${ }^{3}$ King, E. J., and McGeorge, M., Biochem. J., 32, 417 (1938).

4 Briscoe, H. V. A., Matthews J. W., Holt, P. F., and Sanderson, P. M., Trans. Inst. Min. Met., 48, 270, 291 (1937).

${ }^{5}$ Whitehouse, A. G. R., J. Indust. Hyg. Toxic., 20, 556 (1938).

- Emmons, R. C., and Wilcox, R., Amer. Mineralogist, 22, 256 (1937).

${ }^{7}$ King, E. J., "Chronic Pulmonary Disease in South Wales Coal Miners, III", Med. Res. Counc. Spec. Rep. 250, p. 87 (1945).

\section{FIXATION OF FREE NITROGEN BY BARK BEETLES}

\author{
By Prof. J. PEKLO and J. SATAVA \\ Prague
}

$I^{N}$ 1912 and 1916 one of us isolated Azotobacter $(A$. Sulcii) from Afhides, ${ }^{1,2}$. More recently, L. Tóth and others ${ }^{3}$ provd by micro-Kjeldahl determinations that species of Rhynchota (Aphides, etc.) can also rapidly and considerably increase their nitrogen content by futilizing atmospheric nitrogen, though Smith $^{4}$ ha not been able to confirm these results. This year, we made more progress in studying nitrogen fixption by the bark beetle, Ips, which has done much/damage lately in Czech spruce forests.

The larvæ were mostly collected in mountain forests. Over successive intervals they were crushed with oxalacetic acid solution or similar reagent, oven-dried at $100^{\circ} \mathrm{C}$., and subjected to Kjeldahl estimations. Using large amounts $(0.5-0.8 \mathrm{gm}$.), as described by Csaky and Tóth ${ }^{5}$, did not give good results. Samples often showed a decrease in nitrogen compared with the controls. Hence, only small numbers of larvæ (30-50) were used. It was also found that results depended on the age of the larvæ. Half-grown (approximately three weeks old) larvæ fixed atmospheric nitrogen, whereas fully fed and fat ones often showed a decrease. This agrees with our view $^{6}$ that the microbial symbionts of Ips, which occur in the peripheral (so-called adipose) tissue, soon find their way into the alimentary canal, where they are digested. Pupæ and young beetles do not fix nitrogen.

Though they were often found under the bark in great quantities, it was found inadvisable to collect larvæ directly in the forest. It was best to collect large samples (10-15 kgm.) of the infested bark and to isolate the larvæ in the laboratory, grouping them according to size. Even so, it was sometimes difficult to ensure that only one species of $I p s$ was under examination, since several can occur together.

In the first series, using Ips amitinus L., from the Jizerské Mountains, in July 1948, the reagent used was either: (A) 0.088 per cent oxalacetic acid, 0.5 per cent dextrose, 0.7 per cent sodium chloride, 5.4 per cent dipotassium hydrogen phosphate; or $(B)$, which contained 0.2 per cent succinic acid in place of the oxalacetic acid and 9 per cent of phosphate. Both had $p H=7 \cdot 2$, and 3 c.c. were used with each sample of larvæ.

\begin{tabular}{|c|c|c|c|c|}
\hline Sample & $\begin{array}{c}\text { Dry weight } \\
\text { (gm.) }\end{array}$ & $\begin{array}{c}\text { Per cent } N \\
\text { in dry } \\
\text { material }\end{array}$ & $\begin{array}{l}\text { Duration of } \\
\text { fixation }\end{array}$ & $\begin{array}{l}\text { Increase } \\
\text { of } N\end{array}$ \\
\hline $\begin{array}{l}1 \\
2 \\
3 \\
4 \\
5 \\
6 \\
7 \\
8\end{array}$ & $\begin{array}{l}0 \cdot 2466 \\
0 \cdot 2480 \\
0 \cdot 2473 \\
0 \cdot 2552 \\
0 \cdot 3590 \\
0 \cdot 3727 \\
0 \cdot 3634 \\
0 \cdot 3820\end{array}$ & $\begin{array}{l}1 \cdot 7 \\
1 \cdot 92 \\
1 \cdot 81 \\
2 \cdot 08 \\
1 \cdot 52 \\
1 \cdot 46 \\
1 \cdot 61 \\
1 \cdot 57\end{array}$ & $\begin{array}{l}\text { control } \\
13 \mathrm{hr} . \\
24 \quad, \\
48 \quad, \\
\text { control } \\
13 \mathrm{hr} . \\
24 \quad, \\
48 \quad,\end{array}$ & $\begin{array}{l}13 \text { per cent } \\
6 \quad, \\
21 \quad \text { ", } \\
\text { decrease } \\
6 \text { per cent }\end{array}$ \\
\hline
\end{tabular}

Reagent $A$ was used for the first four samples, and reagent $B$ for the others. Oxalacetic acid is considered preferable to succinic acid for this work.

Further results were obtained using samples of the same species from the same locality. Small larvæ and small amounts were used, but with slightly different reagents. Reagent $C$ contained $0 \cdot 1$ per cent of aspartic acid and had a $p H=7.2$; reagent $D$ contained 0.0669 per cent of oxalacetic acid, 1 per cent dextrose and 12 per cent phosphate besides the sodium chloride; its $p \mathrm{H}=7 \cdot 7$. Reagent $E$ was the same as $A$ except for dextrose ( 1.5 per cent) and $5 \cdot 4$ per cent $\mathrm{K}_{2} \mathrm{HPO}_{4}, p \mathrm{H}=7 \cdot 0$. Reagent $F$ contained 0.132 per cent of oxalacetic acid and the higher amounts of dextrose and phosphate, $p \mathrm{H}=7 \cdot 0$.

In the following samples, reagent $C$ was used for 1 and 2 ; reagent $D$ for 3 and 4 ; reagent $E$ for 5 and 6 ; and $F$ for 7 and 8 .

\begin{tabular}{|c|c|c|c|c|}
\hline Sample & $\begin{array}{l}\text { Dry weight } \\
\text { (gm.) }\end{array}$ & $\begin{array}{c}\text { Per cent } \mathrm{N} \\
\text { in dry } \\
\text { material }\end{array}$ & $\begin{array}{l}\text { Duration of } \\
\text { flxation }\end{array}$ & $\begin{array}{l}\text { Increase } \\
\text { of } \mathrm{N}\end{array}$ \\
\hline $\begin{array}{l}1 \\
2 \\
3 \\
4 \\
5 \\
5 \\
6 \\
7 \\
8\end{array}$ & $\begin{array}{l}0 \cdot 0922 \\
0 \cdot 0923 \\
0 \cdot 0950 \\
0 \cdot 0885 \\
0 \cdot 1804 \\
0 \cdot 1798 \\
0 \cdot 3816 \\
0 \cdot 2572\end{array}$ & $\begin{array}{l}2 \cdot 89 \\
3 \cdot 19 \\
3 \cdot 46 \\
3 \cdot 64 \\
1 \cdot 78 \\
1 \cdot 84 \\
0 \cdot 84 \\
1 \cdot 33\end{array}$ & $\begin{array}{l}\text { control } \\
12 \mathrm{hr} \text {. } \\
\text { control } \\
12 \mathrm{hr} . \\
\text { control } \\
12 \mathrm{hr} . \\
\text { control } \\
12 \mathrm{hr} .\end{array}$ & 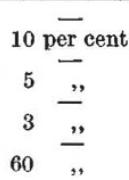 \\
\hline
\end{tabular}

A third series of tests was made with Ips typo. graphus L. and Ips (Pityogenes) chalcographus L., from Broumov Rocks (August 1948), using an oxal. acetic acid reagent.

\begin{tabular}{|c|c|c|c|c|}
\hline Sample & $\begin{array}{l}\text { Dry weight } \\
\text { (gm.) }\end{array}$ & $\begin{array}{l}\text { Per cent } N \\
\text { in dry } \\
\text { material }\end{array}$ & $\begin{array}{c}\text { Duration of } \\
\text { flxation }\end{array}$ & $\begin{array}{c}\text { Increase } \\
\text { of } N\end{array}$ \\
\hline $\begin{array}{r}1 \\
2 \\
3 \\
4 \\
5 \\
6 \\
7 \\
8 \\
9 \\
10 \\
11\end{array}$ & $\begin{array}{l}0 \cdot 1919 \\
0 \cdot 1872 \\
0 \cdot 1819 \\
0 \cdot 2016 \\
0 \cdot 2086 \\
0 \cdot 2142 \\
0 \cdot 1944 \\
0 \cdot 2024 \\
0 \cdot 1887 \\
0 \cdot 1929 \\
0 \cdot 1863\end{array}$ & $\begin{array}{l}1 \cdot 46 \\
1 \cdot 39 \\
1 \cdot 12 \\
1.59 \\
1.67 \\
1.57 \\
1.63 \\
1.28 \\
1 \cdot 11 \\
0.98 \\
1.09\end{array}$ & $\begin{array}{l}\text { control } \\
14 \mathrm{hr} . \\
24 \text {," } \\
\text { control } \\
14 \mathrm{hr} \text {. } \\
24 \quad, \\
48, \text { '” } \\
\text { control } \\
14 \mathrm{hr} . \\
\text { control } \\
14 \mathrm{hr} .\end{array}$ & $\begin{array}{c}\text { Z } \\
\text { - } \\
\text { increase } \\
\text { increase } \\
\text { - } \\
\text { increase } \\
\text { 11 per cent }\end{array}$ \\
\hline
\end{tabular}

In the first three samples, the I. typographus were very small; small to medium specimens were used in samples 4-7 and medium ones in 8 and 9 . The last two samples were young larvæ of $I$. chalcographus. In the first three samples the adipose tissue with symbionts had probably not developed, hence no nitrogen fixation. In the other samples of I. typographus the larvæ werə probably too old, hence only a small increase or decrease of nitrogen was observed. 
In the last two, I. chalcographus definitely fixed free nitrogen.

Another series of samples, also collected at Broumov in August 1948, were similarly treated with the same reagent, samples $1-6$ with 2 c.c. and 7-11 with 3 c.c. I. typographus larvæ Ionger than $4 \mathrm{~mm}$. were used in samples 1 and $2 ; I$. chalcographus (small, young larvæ up to $2 \mathrm{~mm}$.) was used in samples $3-6$; samples 7 and 8 were medium-sized larvæ of the same species (up to $3 \mathrm{~mm}$. in length), and samples 9-11 consisted of larvæ up to $5 \mathrm{~mm}$. long.

\begin{tabular}{|c|c|c|c|c|}
\hline Sample & $\begin{array}{l}\text { Dry weight } \\
\text { (gm.) }\end{array}$ & $\begin{array}{c}\text { Per cent } N \\
\text { in dry } \\
\text { material }\end{array}$ & $\begin{array}{c}\text { Duration of } \\
\text { fixation }\end{array}$ & $\begin{array}{c}\text { Increase } \\
\text { of N }\end{array}$ \\
\hline $\begin{array}{l}1 \\
2\end{array}$ & $\begin{array}{l}0 \cdot 1597 \\
0 \cdot 1604\end{array}$ & $\begin{array}{l}1 \cdot 36 \\
1 \cdot 44\end{array}$ & $\begin{array}{l}\text { control } \\
13 \mathrm{hr} \text {. }\end{array}$ & about \\
\hline $\begin{array}{r}3 \\
4 \\
5 \\
6 \\
7 \\
8 \\
9 \\
10 \\
11\end{array}$ & $\begin{array}{l}0 \cdot 1457 \\
0 \cdot 1414 \\
0 \cdot 1492 \\
0 \cdot 1423 \\
0 \cdot 2211 \\
0.2314 \\
0.2348 \\
0 \cdot 2388 \\
0 \cdot 2356\end{array}$ & $\begin{array}{l}\text { lost } \\
1 \cdot 09 \\
1 \cdot 27 \\
1 \cdot 33 \dagger \\
1 \cdot 39 \\
1 \cdot 59 \\
1 \cdot 43 \\
1 \cdot 41 \\
1 \cdot 39 \ddagger\end{array}$ & $\begin{array}{l}13 \overline{\mathrm{hr}} \cdot{ }^{*} \\
26 \mathrm{.}, \\
72 \text { control } \\
13 \mathrm{hr} . \\
\text { control } \\
13 \mathrm{hr} . \\
26, "\end{array}$ & $\begin{array}{r}{ }_{6}= \\
21 \quad, \\
14 \\
= \\
= \\
=\end{array}$ \\
\hline
\end{tabular}

* Control. $\dagger$ In contrast with 4 . $\ddagger$ Larvæ too old.

Thus, on the whole, in all four series there is an increase in the nitrogen content of the larvæ, agreeing with our cytological considerations. This also coincides with the rapid breeding of these insects, though it is not so remarkable as with Aphides. It affords an explanation of the damage caused by $I p s$, and the question arises whether this behaviour can be controlled and even put to some use.

More than a hundred eggs as well as many larvæ were used in order to isolate the symbiotic organisms. In the adipose tissues it is mainly Torulopsis (Crypto. coccus), an extremely variable organism, in contrast with previous experience. In addition, many strains of Candida were isolated as well as various species of bacteria, some resembling Azotobacter.

1 Peklo, J., Ber. d. bot. Ges., 30, Na. 7 (1912).

${ }^{2}$ Peklo, J., Zemédelsky Archiv., vii (1916).

'Tóth, L., et al., Z. f. vergl. Physiol., 30, 67 (1942) ; 32, 300 (1944)

- Smith, J. D., Nature, 162, 930 (1948).

${ }^{5}$ Csaky, T. Z., and Tóth, L., Experientia , 4, 73 (1948).

- Peklo, J., Nature, 158, 795 (1946).

$$
12=
$$

\section{MUSHROOM RESEARCH STATION AT YAXLEY}

$$
\begin{aligned}
& \text { By DR. R. L. SOtVARDS } \\
& \text { Director } \text { Research }
\end{aligned}
$$

$\mathrm{R}$ ESEARCH on sq of the problems of mushroom growint has been carried on for many years, particularly in France and in the United States. TR aspects have received special attention -tha chemjeal and microbiological changes in horse manu vuring composting, and the fungus diseases of mushrooms and mushroom beds. The principal British work on mushroom cultivation is that of Ware on diseases and of Pizer on horse-manure composts. Recently the mechanization of transport has caused an increasing shortage and rise in price of horse manure, and this has become a major problem. Research on synthetic composts was in progress in the United States twenty years ago, and several formulæ have been published; but many of the materials used are not available in Great Britain. Since the end of the War, American growers and research workers have devoted more attention to methods of using the available supplies of horse manure more economically, and to mechanization of their cultural operations. Synthetic composts are not widely used. Some work on synthetic composts was done in France during the 'thirties, but horse manure is still the only medium used commercially.

In 1945 a group of British mushroom growers decided to set up their own research station at Yaxley, with the development of a commercially satisfactory synthetic compost as the main problem. A laboratory, two test-houses, and a covered turning shed were built, and work started in 1946. Six experimental crops have been grown during the past three years, and the main requirements for making a productive synthetic compost from wheat straw have been established. Small-scale tests on a commercial farm have given a yield comparable with the best obtained from horse manure.

As a result of consultations between the Mushroom Research Association, Ltd., which has financed the research station until now, the Mushroom Growers' Association (a specialist branch of the National Farmers' Union) and the Ministry of Agriculture, arrangements are being made for the Research Association to receive a grant from the Ministry and to publish all its results.

Each main cropping-experiment now includes twenty-four composts of about half a ton each, made up side by side in two rows, and separated by iron sheets, so that aeration and losses of heat and moisture are similar to those occurring in one long stack of compost. In this way the replicated comparisons and factorial experiments familiar in agricultural research can be carried out. Analyses and microbiological examinations of the composts are made at suitable stages. Some of the results obtained in this way are likely to interest workers on agricultural composts.

The main nutrients studied are nitrogen, phosphorus, potassium and calcium. The source of nitrogen is very important, organic nitrogen giving higher yields than the inorganic forms so far tested. An empirical mixture of twelve trace-elements has quite a pronounced effect; one problem for the future is to determine which of these are essential and in what proportions. Preliminary experiments with growth substances suggest that further work in this field may give results of practical value, in addition to its scientific interest. The number of mushrooms produced has been increased in several experiments, and earlier fruiting has been obtained.

Variations in the depth of beds and in the intervals at which spawn is sown have quite marked effects on the time of fruiting and on yield. In the course of these experiments the number and size of mushrooms produced are recorded daily, and some measurements of their rate of growth and the relation between dimensions and weight are made. In several instances factors affecting the number of mushrooms produced have been distinguished from those affecting their size, and this work will add much to our knowledge of the appearance of mushrooms in fiushes, the opening of the veil, which is subject to considerable variations, and the exhaustion of mushroom beds. These fundamental aspects of mushroom 'macro. biology' have been almost entirely ignored in the past, and their elucidation is of scientific and practical interest. 